\title{
VOTER ABSENTEEISM IN THE LOCAL GOVERNMENT ELECTIONS IN POLAND IN 2006
}

\author{
by Teresa Sasińska-Klas
}

Citizens are the most characteristic element of a democracy

(P. C. Schmitter, T.L. Karl)

\begin{abstract}
Numerous public opinion polls conducted in Poland since the 1990s have tried to answer questions linked with the processes of installing, and later stabilizing the new democratic order. Theoretical considerations were conducted on the basis of political science, sociology, and communications studies dealing with the democratic system, tended to concentrate on procedural questions as well as in institutional frameworks dealing with the functioning of the democratic system. Analyses dealing with the social reception of the political transformations and their reflection in the state of social awareness most often were in reference to the situation concerning successive political elections. It would appear the linking of these research approaches, of the so-called theoretical studies of the democratic process in the political system as well as empirical findings, and also perceived social signals resulting from public opinion research, may lead to the creation of more valuable results, as well as the posing of new research questions.

Over the course of the last twenty years or so, a significant decrease in socialpolitical activity, together with a depletion of confidence which citizens have in democratic institutions may be observed. Similar trends are also discernible in other countries with many years of democratic traditions (such as the USA). Steadily falling voter turnout has not - and this fact should be stressed - been a factor unique
\end{abstract}


to Polish society. This diminishing voter turnout is evident in other countries with a relatively brief history of democratic institutions, such as in Lithuania or Russia. There are other countries where voter turnout is rather high, such as in Scandinavia, some countries of the Mediterranean basin, Australia, etc. In some of these countries, mandatory voting is institutionalized. This solution functions in several European countries, such as Belgium, Greece, Portugal, Switzerland, and in Italy. Voter turnout therefore, has a different significance in these countries. What does the situation look like in Poland?

The majority of citizens did not participate in the last parliamentary and presidential elections held in Poland, in 2005, and thereby did not make a political choice. Less than half of the adult citizens eligible to vote, did so. The situation was similar in the local elections held in the autumn of 2006, despite an increase in the level of education of the electorate, and a broadening of their knowledge of how the democratic system works, and of their experience of living in a democratic society, a definite tendency of a lowering of what was a heretofore not exceptionally high participation in the democratic process may be observed. This may be detected in the low vote turnout for presidential, parliamentary, and local elections. It is an irrefutable social fact, although markedly detrimental to society as a whole. Not only may Polish society be regarded as one where the individual citizen's participation in the democratic process is low, it is constantly falling.

It would therefore seem well founded, to subject the following problem, which provokes a question, the answer to which is difficult, to analysis, that is: "Why do so few adult citizens participate in successive elections in our country, and more exactly, why are there successively fewer and fewer of them?" What is the cause of this state of affairs? Is there a cumulative effect, that is, should we expect even fewer citizens to participate in future elections than in 2005 and 2006? Should we take into consideration the fact that those who weren't present, those non-participants in the elections are ever greater in number, and are a more numerous social group than those who vote. Is this an indication of a permanent change, or is this political mechanism of participation/non-participation seasonal? Is it therefore sound to maintain the heretofore electoral procedure, if the majority doesn't participate and "turns it's back on politics"? Is there any chance to stem the tide of an ever-increasing lack of voter participation? And finally, what does all of this mean?

The participation of citizens in political life constitutes one of the most important characteristics of democracy. The democratic political culture is a culture of citizens' participation in social life. Participation in politics is defined in political literature as a "an engagement (by people) of their own free will, with the goal of obtaining specific political results, such as the selection (rejection) of those governing, as well as the 
taking/not taking of binding decisions".' Political participation by citizens is their form of exerting political influence, by determining who will wield power in the state over the course of the next term of office of parliament, in local government, or in the case of those persons who will exercise power in the highest office of the state, that is, that of president, chancellor, etc. A high level of political participation is, - as Artur Noga-Bogumilski writes - an indication "of a participatory political culture, distinguished by a relatively high consciousness of the political mechanisms and a tendency by the citizens to take an active part in politics and the wielding of authority".'

Political participation demands that citizens possess the essential quantum of knowledge concerning political processes and mechanisms, a consciousness of their own goals as linked with the political system in which they function, and also of the posture of engagement in political activity through the expression of support, undertaking tasks and obligations linked with the attaining of given political goals. It's necessary to accept, as basic forms of political participation, the following tenets:

a) participation in elections and referendums

b) taking part in electoral campaigns

c) membership in political parties and participation in social movements

d) individual contact with politicians ${ }^{3}$.

Political activity is highly desirable in any society, as it allows accepted political goals and demands to be achieved more effectively. What's at stake here, above all, is a pro-system activity, supporting the essence of a given political system, and not anti-system activity, aimed at the political system as a whole. ${ }^{4}$

The process of political socialization of the citizen, which is realized in the realm of a given state, serves this goal. It is accepted that a higher level of participation on behalf of the citizens serves this goal, and aids the process of legitimization of the authorities and therefore contributes to a higher level of democratization of the political system as a whole.

An observation of social life nevertheless indicates, that the degree of interest of citizens in the political sphere has a tendency to fall. In most democratic countries, the number of people who take an interest in politics and manifest readiness to

1 This is a definiton formulated by G. Meyer, which is included in his considerations at: Demokracje zachodnioeuropejskie. Analiza porównawcza, A. Antoszewski \& R. Herbut (ed.), Wydawnictwo Uniwersytetu Wrocławskiego, Wrocław 1997, p. 211.

2 A. Noga-Bogomilski, J. Garlicki, Kultura polityczna w społeczeństwie demokratycznym, Oficyna Wydawnicza ASPRA-JR, Warszawa 2004, p. 110.

3 See: System partyjny i zachowania wyborcze. Dekada polskich doświadczeń, R. Markowski, (ed.), Instytut Studiów Politycznych PAN, Warszawa 2002, p. 51 and n.

${ }^{4}$ Zob. Ibidem. 
participate in the political process does not exceed twenty per cent. Indeed, a decrease in the percentage of people who actively and willingly participate in the political process may be observed. A digression of this regressive trend may be observed in situations linked with elections where citizens who normally don't participate in the political process, start to express an interest in elections, in the candidates for various political offices, in a climate of controversy over proposed political programs, and election promises, etc. A similar mechanism comes into play in situations of political conflicts and disputes, or during extreme crises. It's at this time that certain citizens "wake up" from their state of political indifference, and start to form their own opinion regarding the issue which is at the center of the controversy. ${ }^{5}$

Since the beginning of the 1990s, a process may also be observed in Poland, of a decrease of participation by citizens in elections, on all levels of the electoral process. This situation contributes to a weakening of participation as a model of political culture. This is due to the fact that is does not suffice to be formally eligible to participate in the decision-making process, selecting representatives of political parties for parliament or for local government, or even for determining who the next president will be. What is essential, is how these rights are used - this is an indicator of the level of democracy in a political system well as of the level of political culture which the citizens possess... knowledge, values, opinions and judgments about the democratic system are not enough, equally important is the direct political behavior of the electorate within the boundaries of the functioning political system. If there is a lack of any of these elements, or if they manifest a tendency to be in a state of regression, at that time, model political culture participation loses significance in favor of a parochial political culture, as proposed by Gabriel Almond. ${ }^{6}$

"Voting is an indication of democracy" writes Paweł Kozłowski ${ }^{7}$ and he adds, that it is us who decide whether to vote or not, and nobody can make that decision for us. This means, that in a democratic system, citizens always find themselves in a situation of an approaching election, for example, they will take place in accordance with the electoral calendar, in three or four years, or they are in a period after elections, which means that practically permanently, they are in a situation of approaching political elections or determining results of elections which recently took place. Ralf Dahrendorf stresses that "political rights are an admission ticket for active citi-

\footnotetext{
${ }^{5}$ Ibidem.

6 See more on this subject in a work by: Almond, G.A., Verba, S.C., The Civic Culture, Princeton University Press, New York 1963.

7 P. Kozłowski, Szukanie demokracji. Edukacja obywatelska, Prószyński i S-ka, Warszawa 2001, p. 138.
} 
zens" ${ }^{8}$.This is why sociologists and political scientists stress how important citizens' participation is in a democracy, as well as their active participation in creating a society9. These active individuals are called citizens, and only if their level of activity is high, may we speak of a citizen's society ${ }^{10}$.

\section{VOTER ABSENTEEISM - POLITICAL PASSIVITY OR POLITICAL ABSENCE?}

Voter absenteeism is defined by such terms as voter passivity, non-voting, electoral non-participation, electoral absence, and deals with "the phenomenon of non-participation by citizens empowered to vote, in the electoral process". "The level of the degree of absence in elections is interpreted as a weak acceptance or lack thereof, of participating in undertaking any democratic decisions. Over the last few years, a definite tendency of decreasing voter turnout, in what had already been low, has been observed. The majority of adult citizens do not participate in elections, that is, they don't make any decisions in this sphere, which means that the electoral decisions made by the minority don't include the majority which didn't participate in the elections. This remains however, in close union with a marked, continually weakening level of legitimization of those who exercise authority, who are themselves chosen by fewer and fewer people.

The renowned American political sociologist, Martin Seymour Lipset ${ }^{12}$ (who recently passed away) conducted research on vote turnout and absenteeism at the end of the 1950s. The results of his research, which were attained on the basis of an analysis of American society, have been employed and confirmed in similar research conducted in several European countries, such as Germany, Sweden, Norway, and

${ }^{8}$ R. Dahrendorf, Nowoczesny konflikt społeczny. Esej o polityce i wolności, Warszawa 1993.

${ }^{9}$ M. Magoska writes extensively on the subject in her work, Obywatel $w$ procesie przemian, Wydawnictwo UJ, Kraków 2001.

${ }_{10}$ R. Paradowski, Społeczeństwo obywatelskie a demokracja, [in:] Czas społeczeństwa obywatelskiego. Między teoria a praktyką, B. Krauz-Mozer \& P. Borowiec (eds.), Wydawnictwo UJ, Kraków 2006, p. 123.

"Encyklopedia politologii, M. Żmigrodzki (ed.), Kantor Wydawniczy "Zakamycze”, Kraków 1999, Vol. 1, p. 13.

${ }_{12}$ M.S. Lipset, Homo politicus. Społeczne podstawy polityki, Wydawnictwo Naukowe PWN, Warszawa 1995. 
Finland ${ }^{13}$. They have shown that the following attributes have exerted an influence on low voter turnout/voter absenteeism in elections:

1) low income

2) low level of education

3) being under 35 years of age

4) marital status - those who are not married tend to vote less frequently

5) sex - women are more likely not to participate in elections

6) occupation - unskilled laborers, service-area workers, and farmers tend to vote less frequently

7) those who have recently become part of society ${ }^{14}$.

Therefore, social-demographic factors, such as education, income, or professional status, exert an essential influence on participation (or lack thereof) of citizens in political life. Research performed by a Norwegian sociologist, Stein Rokkan, together with his team, indicates that in the so-called young democratic countries, (Poland is included in this group of countries) a relatively low level of political activity is registered among the citizens. These countries tend to head in the direction of transforming the political life of citizens into a sphere of activity for an elite. The researchers recognize this trend as being highly unprofitable, especially in those societies, where the democratic experience has existed for less than twenty years. ${ }^{15}$

In Poland, Krystyna Skarżńska, amongst others, has been concerned with participation in politics, and in light of the analysis carried out be her, it occurs that conventional political activity predominates among adult Poles. That is to say - in her opinion - this activity is linked with a position of subservience in face of the demands and expectations of the political system as well as those social norms considered to be socially important for citizens. This is also most often the only form of political participation by citizens. Non-conventional forms of activity also occur, these types of activity would include: actively supporting politicians or political parties, (membership in a party understood to be active participation), activity on a local scale, expressing protest or social dissatisfaction, and others. Unconventional forms of activity are undertaken by a small number of sympathizers and adherents of a given party or political option.

Conventional participation - in a statistical sense - which in Poland commenced with the parliamentary election in June,1989 until the present moment, has vacillated

13 Ibidem, p. 194.

14 Ibidem, p. 196.

15 The results of research carried out by S. Rokkan together with his team is described by J.J. Wiatr in his work Socjologia polityki, Wydawnictwo Naukowe Scholar, Warszawa 1999, pp. 292-293. 
at a level of from $40 \%$ to $60 \%$ of those citizens eligible to vote. Practical experience in this sphere has indicated, that the transition from the phase of an electoral battle, to the phase of working out a positive social consensus, as well as the stabilization of the democratic system, is still complicated and far short of accepted expectations in the sphere of shaping the political culture of society. The statistics presented below, regarding voter turnout in Poland from 1989-2006, confirm this state of affairs.

Tab. 1. Voter Turnout in Poland 1989-2006.

\begin{tabular}{|l|c|}
\hline \multicolumn{1}{|c|}{ Elections } & Turnout in \% \\
\hline $\begin{array}{l}\text { Parliamentary Elections in 1989 (June) } \\
\text { I Round }\end{array}$ & 62,50 \\
II Round & 25,10 \\
\hline Local Government Elections in 1990 (May) & 42,30 \\
\hline Presidential Elections in 1990 & 60,60 \\
$\quad$ I Round (November) & 53,40 \\
\hline II Round (December) & 43,20 \\
\hline Parliamentary Elections in 1991 (October) & 52,10 \\
Parliamentary Elections in 1993 (September) & 33,80 \\
\hline Local Government elections in 1994 (June) & \\
\hline Presidential Elections in 1995 & 64,70 \\
\hline I Round (November) & 68,20 \\
\hline II Round (November) & 47,90 \\
\hline Parliamentary Elections in 1997 (September) & 46,00 \\
\hline Local Government Elections in 1998 (October) & 61,10 \\
\hline Presidential Elections in 2000 (November) & 46,30 \\
\hline Parliamentary Elections in 2001 (September) & 44,00 \\
\hline Local Government Elections in 2002 (October) & 40,57 \\
\hline Parliamentary Election in 2005 (September) & 49,74 \\
\hline Presidential Elections in 2005 & 50,99 \\
I Round (October) & 53,99 \\
II Round (October) & \\
\hline Local Government Elections in 2006 (November) & \\
\hline Parliamentary Elections in 2007 (October) & \\
\hline & \\
\hline
\end{tabular}

* See the official results given by the Państwowa Komisja Wyborcza (State Election Commission) a http://wiadomości.onet.pl/wybory 2007.

One may easily discern, that throughout this period from 1989 to 2006, a somewhat low turnout amongst adult Polish voters predominated, and only the presiden- 
tial elections enjoyed the highest turnout throughout that 18 -year period. What is noteworthy however, is that the lowest turnout, and hence the lowest level of voter interest, occurred at the local level, where the effects of a political decision are directly felt by the citizens. Even here, voter turnout did not exceed fifty per-cent of those eligible to vote.

Research in public opinion has shown that, commencing with the changes in the political system initiated in 1989, participation by adult citizens in elections was to a great degree an act of moral support for the changes taking place, and a lack of participation - to a significant degree was a manner of expressing a type of social opposition to the reforms taking place. Therefore participation to a great degree meant social support for the changes being conducted, and not the making of a rational choice for one or another political option or for a candidate for a specific office. Research polls conducted in 1992 showed that $25 \%$ of adult Poles - members of local government - participated in the elections "to show support for the changes". ${ }^{16}$ However, only $14 \%$ of the electorate took part in the elections because of a feeling that as citizens they were exerting an influence on the political sphere. In successive, early parliamentary elections, which were held in 1993, the dominant motive for participating in elections was the conviction of a possibility of exerting a real influence on the political scene. Nevertheless - in light of signals resulting from research of public opinion held in 1997, in the period immediately preceding the parliamentary elections, it turned out that more people said they would participate in the electoral process, than actually took part. Therefore in light of experience obtained over the last few years, it must be affirmed (for example in the local government elections held in 2002 and 2006 a similar tendency was noted) that about $1 / 3$ of adult Poles who declared that they would take part in the elections, failed to do so. In addition, this tendency has remained consistent until the present time, which indicates that the level of social recognition for participation in elections has a higher social acceptance than the level of real electoral behavior.

\section{TYPES OF VOTER ABSENTEEISM}

There are several causes which contribute to voter absenteeism. Those citizens who do not participate in elections, as well as the motives lurking behind this behavior, are the subject of this analysis. A majority of the electorate does not participate

\footnotetext{
${ }^{16}$ Ibidem, p. 46.
} 
in elections. Do they do this consciously or unconsciously? Literature dealing with the subject points to two types of absence in elections: culpable and obligatory. ${ }^{17}$

Culpable voter absenteeism occurs when the voter consciously refuses to vote. In other words, he "consciously turns his back on politics". He is absent in elections and many factors contribute to this absence. Absence in election may be a result of a lack of confidence in politicians, a low sense of the importance of an individual citizen, a lack of an electoral alternative, or simply no interest in politics.

We may speak of an obligatory absence, when the voter wants to vote, but because of causes beyond his control is unable to do so. An example of this type of absence would be non-participation in elections by elderly people who live far away from their voting station, or handicapped people, who due to their infirmity have a limited ability to move around and physically get to their voting station may have an insurmountable obstacle that prevents them from voting. An obligatory absence may be due to the fact that the voter has other pressing obligations that need to be fulfilled on election day, for example, he may be away on business, either in Poland or abroad, he may be studying at a university in another city than where he permanently resides and is registered to vote, or being a university student, may reside on campus, far away from his permanent domicile. In these conditions, we are dealing with an obligatory absence, because we may assume that if it weren't for those conditions rendering it impossible for the individual voter to participate in the election, he would vote. Significantly more important and socially more complicated, is a situation involving culpable absence, because this signifies a conscious refusal to participate in the election. There is a lack of complete knowledge as to the scale of this phenomenon in Poland, nevertheless more and more often observers and analysts of the political scene are undertaking research to determine the motives and causes of this unfortunate state of affairs in our country. ${ }^{18}$

The mandatory voting procedure in our country, must be considered to be one of the most conservative in Europe, as in accordance with the election law, one may

17 Aktywny obywatel, nowoczesny system wyborczy, L. Kolarska-Bobińska (ed.), Instytut Spaw Publicznych, Warszawa 2006, p. 16.

${ }_{18}$ An example of just such an accurate and deep analysis on the subject is the work by K. Kulig, Absencja wyborcza w Polsce na przykładzie wyborów parlamentarnych i prezydenckich 2005 oraz samorzadowych 2006 - an MA thesis, defended in the Institute of Journalism and Social Communication at the Jagiellonian University in Kracow, 2007 as well as D. Giza, Obecność czy nieobecność? Poziom uczestnictwa młodzieży w wyborach parlamentarnych, prezydenckich i samorzadowych w 2005 i 2006 roku - an attempt at an analysis, an MA thesis defended at the Institute of Journalism and Social Communication at the Jagiellonian University in Kracow 2007. 
only vote in person, in the precinct where one is registered. ${ }^{19}$ The bill which recently updated local government from September 6, 2006, that is two months before planned local government elections, (the elections took place on November 12, 2006) changed nothing in this sphere. It didn't aid voters, who are fewer and fewer, who were going to vote at their local polling stations, to cast their ballots in a more modern fashion, for example electronically via the Internet. Recent experience from other countries, amongst others from Europe as well, shows that using new information technology can help voters, for example those who are abroad or those who are far away from the district where they are registered, to vote via the Internet. What was newly introduced however by the new bill updating the election code? The new ordinance permits parties to form coalitions and make agreements regarding how mandates will be divided, that is making so-called blocks. From the voter's viewpoint, if he casts his vote for party $\mathrm{X}$, and that party forms a coalition with party $\mathrm{Y}$, there are two scenarios of what may happen to his vote. If the voter casts his ballot for party $\mathrm{X}$, and that party receives the minimum of votes required, that party will determine what will become of his vote. If party $\mathrm{X}$ doesn't receive the minimum amount of votes to be in parliament, party $\mathrm{Y}$, the coalition partner, will receive the vote cast for party $\mathrm{X}$. How did potential voters react to these changes in the local government elections in 2006? Did they manifest more interest in the approaching elections and a greater readiness to participate in them?

In a report based on research performed on public opinion carried out by the Center for Public Opinion Research, Agnieszka Cybulska shows how Polish voters react to the most recent changes in the election law concerning local government elections: "an evaluation of the change in the electoral ordinance for local government, as performed two months before the elections, was difficult for Polish electorate. These changes were for the majority of those polled, relatively difficult to understand and rather unknown - more than $40 \%$ hadn't even heard about their introduction, approximately one third had heard something about them, but didn't have detailed knowledge of the subject. Only one quarter of those eligible to vote declared they had some orientation of the new regulations dealing with the creation of electoral blocks. Almost half of those polled was neither "for" nor "against" the possibility of creating so-called voting blocks - almost one fourth had no opinion on the subject, and the same amount declared indifference to the changes introduced. Amongst the remainder of those polled, the creation of voting blocks, has twice as

19 There is only one exception to this principle, limited to a very narrow group of people. That is, those in hospitals and clinics, where patients are visited by people from the voting commission who come to them with a voting urn and they can cast their ballots while still remaining in bed. 
many opponents as adherents. The political parties in parliament which voted for these changes PiS (Law and Justice), Samoobrona (Self-Defense), and LPR (The League of Polish Families) are most often cited as the principal beneficiaries of these changes. ${ }^{20}$

Therefore, as the research indicates, the modified ordinance has shown itself to be incomprehensible for the majority of voters, or they were unconscious of the fact that the party they were voting for had "formed a block" with another political party. At any rate, public opinion polls conducted by the Public Opinion Research Center, on what adult citizens think about the changes in the election ordinance, revealed that these changes were performed because of a political incentive to maintain and even strengthen the representation of small parties did not contribute to decreasing voter absenteeism, on the contrary - it helped lower voter turnout. ${ }^{21}$ The new law however did not take advantage of the possibility of expanding electoral possibilities, by Internet voting, even though such a solution has already been employed in other countries such as in the United States, India, and Australia, whereas experiments in electronic voting (e-voting) have been conducted in European countries such as Holland, Belgium, Great Britain, and in Sweden.

\section{WHO IS THE POLISH NON-VOTER?}

Just who are the absentee voters and why didn't they participate in the elections? Many different analysts of the political scene have been trying to answer those questions, especially immediately after elections when questions like "Why did so few people vote?" or "What was the cause?" are posed. Politicians who occupy public offices as a result of a choice made by society, are painfully aware of the fact that their electoral victories are based on the support of an ever narrower sector of society. In their future activities in local government or in parliament, they will be obliged however, to appeal to their electorate, and also those who didn't vote at all, and take into consideration the viewpoints of the former as well as of the latter. It's a difficult challenge, with no guarantees of success. What therefore makes voters turnout in fewer and fewer numbers?

20 See: Report no BS/149/2006: Polacy o zmianach ordynacji wyborczej do wyborów samorzadowych, CBOS, Warszawa, October 2006, p. 9. The survey was performed on 8-11. 09.2006, namely just after the change and its signing by the President of Poland on 7.09.2006. The survey was performed on 937 adult citizens of Poland.

21 See: Report no BS/142/2006: Polacy o zmianach ordynacji wyborczej do wyborów samorzadowych, CBOS: Warszawa, October 2006, and Report no BS/5/2007: Czynniki wptywajace na decyzje w wyborach samorzadowych, CBOS, Warszawa, January 2007. 
Elections are an opportunity for citizens to make a rational choice. It is they who determine in which direction for the next four or five years the state will develop. Only forty percent of the citizens exercise that right in our country ${ }^{22}$. That is a low indicator of political participation.

The election campaign in the local government elections in 2006 was exceptionally poorly visible. None of the parties running for office in these local government elections did anything to increase voter turnout. The change in the election law two months before the elections, disoriented potential voters. Some $69 \%$ of adult Poles declared in public opinion polls, that the changes introduced had no influence on their decision to participate or not in the elections. ${ }^{23}$

One seventh (15\%) of adults declared that the changes carried out discouraged them from voting in the upcoming local elections. In fact, voter absenteeism in the local government elections in 2006 was significantly higher and mounted to $54.1 \%$ in the first round, and grew even more, to $60.31 \%$, in the second round. ${ }^{24}$

In spite of the fact that potential voters indicated in September 2006 that the modified election law did not exert a critical influence on their voting behavior, they nevertheless declared that voting is important for them, indeed $60 \%$ said that the elections were very important for them. ${ }^{25}$ In October 2006, the percentage of the electorate who said that they would participate in the next elections rose to $57 \%$, (in September, $56 \%$ of adults declared that they intend to vote, of which $37 \%$ said that they would certainly vote in the next elections). ${ }^{26}$ Real voter turnout however, was substantially lower than what was predicted by potential voters.

What did Polish non-voters manifest in the local government elections of 2006 ? - an ever increasing distance between society and politics, and a deepening tendency to "turn their backs" on politics. These attitudes appeared in the Polish electorate regardless of age or level of education. These same attitudes are also noted among those voters, who declare that they are interested in public life. What is it therefore, that so effectively discourages ever increasing numbers of Poles from going to the voting booth and expressing their political preferences or even lack thereof? We cannot simply affirm that non-participation in elections is a lack of an electoral preference. This is very often an expression of a conscious refusal of a type of

22 T. Lis, Polska głupcze, Świat Książki, Warszawa 2006, p. 67.

${ }^{23}$ Report no BS/149/2006, Polacy o zmianach..., op.cit., p. 8.

$24 \mathrm{http}: / /$ pl.wikipedia.org.wiki/Wybory_samorz\%C4\%85dowe_w_Polsce_2006

${ }_{25}$ Report no BS/133/2006: O wyborach samorzadowych, CBOS, Warszawa, September 2006, p. 4.

${ }^{26}$ Report no BS/157/2007: O wyborach samorządowych na niespetna miesiąc przed głosowaniem, CBOS, Warszawa, October 2006. 
political behavior that is expected of, and socially highly desirable, of citizens. Polish non-voters are declaring that they are discouraged with what is taking place on the political scene, and that their votes are powerless to change the situation (potential voters ask themselves the question in union with the approaching elections: "Does my participation in these elections make any sense at all? - and the response, most often is negative). Hence, many Polish non-voters have come to the conclusion that the best expression of their relationship to that which is taking place in public life, is their absence in elections. That is an irrefutable social fact.

The consequences of this state of affairs are much more serious and complicated, as the democratic system cannot effectively develop in a situation, where the electoral passivity of a majority of society has become a universal standard. The high level of voter absenteeism in parliamentary, presidential, and local government elections has a negative influence on the government's legitimacy, as well as on the legislative branch (parliament), as on the executive branch (the prime minister, his cabinet, and the presidency), and is therefore not an adequate reflection of the representation of the political interests of the citizens. With more than half of adult citizens not participating in representative, that is parliamentary and local government elections, we can only know the preferences, expectations, and solutions as performed by a minority of the electorate. Meanwhile the majority, which didn't express its opinion in the voting booth, may not necessarily support and confirm solutions which they did not participate in finding. Elections are held so that society's expectations may be made known, and so that citizens may render support to these expectations. Whenever this is lacking on an ever-greater scale, a deficit in legitimacy, which is expressed in a lack of expected social behavior, becomes the logical consequence of this state of affairs and leads to the creation of socially unprofitable state of sociopolitical awareness, which in the functioning of a democratic system, that is one based on obtaining the necessary social support and confidence, a high risk concerning effective governing appears. More and more often one hears the opinion that refraining from voting by a majority of the adult population, is also a manner of expressing one's political opinion! It's not just those who don't have a crystal-clear preference who don't vote, but also those who don't manifest their expectations, even in spite of the fact, that they do posses expectations. The ever rising tide of lack of citizens' participation can no longer be ignored, as it attests to the low quality of politics and politicians, that is, of those who want to be elected, to carry out their functions, possessing a mandate of social support and confidence.

In conclusion, I would like to quote a postulate, which was said by Tadeusz Mazowiecki, the first Prime Minister of the first non-communist government which was elected in 1989 in Poland, as a result of the surprising results, for those governing before these elections, that is a victory of "Solidarity", that: "Poland needs a citizen's 
presence, which gives strength to the electoral process today and in the future. Passivity and resignation, at times in history, have spelt the death knell of democracy". ${ }^{27}$

We should express the hope, that this postulate will be taken into serious consideration in the near future by those who exercise authority, as well as by the citizens in general, who grant permission in elections to their elected representatives, to represent their social interests.

27 T. Mazowiecki, Trzeba głosować!, “Gazeta Wyborcza” 2006, No 263, p. 29. 